Article

\title{
The Relationships among Environments, External Knowledge Acquisition, and Innovation
}

\author{
Kwangsoo Kim ${ }^{1}$, Fan $\mathrm{Li}^{2}$, Jae Wook Yoo ${ }^{1}$ and Choo Yeon Kim ${ }^{1, *}$ \\ 1 College of Business Administration, Konkuk University, Seoul 05029, Korea; kkim@konkuk.ac.kr (K.K.); \\ jwyoo@konkuk.ac.kr (J.W.Y.) \\ 2 Bank of Communication, Beijing 101121,China; lif_225@bankcomm.com \\ * Correspondence: chookim@konkuk.ac.kr
}

Received: 22 June 2020; Accepted: 6 July 2020; Published: 9 July 2020

check for updates

\begin{abstract}
The purpose of this study is to investigate the mediation effects of external knowledge acquisition on the relationships between environments (dynamism, complexity, and hostility) and innovation. Although prior studies have extensively examined the relationships between environments and innovation or innovativeness, the results of the studies appear to lack consistency. To help clarify the relationships between environments and innovation, this study intends to examine the impact of environments on innovation through external knowledge acquisition, and it is argued that environments are likely to motivate or force firms to acquire new knowledge from the outside, which, in turn, tends to enhance their ability to innovate. Based on data collected from manufacturing SMEs in China through a questionnaire survey, we have found that dynamism, complexity and hostility have all positive total effects on innovation and that they also have positive influences on firms' external knowledge acquisition. Besides, we have found that external knowledge acquisition has a complete mediation effect on the relationships between all three environmental dimensions and innovation. The results further show that the positive direct effects of all three environmental dimensions on innovation disappear completely when external knowledge acquisition is considered as a mediator. These results imply that the significant relationships between three respective environmental dimensions and innovation demonstrated in prior studies may be spurious. Based on these findings, we have presented key conclusions, implications, and limitations with the direction of future research.
\end{abstract}

Keywords: environments; dynamism; complexity; hostility; external knowledge acquisition; innovation

\section{Introduction}

In the era of the Fourth Industrial Revolution, the importance of innovation or innovativeness for firms' survival and success has grown significantly, and firms' interest in innovation or innovativeness has also increased. In this regard, researchers have paid a lot of attention to studying the factors affecting corporate innovation, especially external environments influencing corporate innovation [1-4]. According to the literature, the relationships between environments and innovation or innovativeness have been extensively studied [1-4]. The existing research on this topic has empirically investigated the effects of various environmental dimensions, such as dynamism [5,6], complexity $[3,4]$, hostility $[4,7]$, technological turbulence $[8,9]$, market turbulence $[9,10]$ and competitive intensity $[10]$ on innovation or innovativeness.

Although firms' innovation outcomes have long been viewed as reflections of their operating environments in these studies, the empirical results of the environments-innovation relationships seem to be rather incoherent, and even conflictive sometimes, as shown in Appendix A. For example, Pervan, Al-Ansaari, and $\mathrm{Xu}$ [5] and Alexandrova [11] have empirically demonstrated a positive effect 
of environmental dynamism on innovation or innovativeness, respectively, while Tuominen, Rajala, Möller, and Anttila [12] have shown little or no significant effect of environmental dynamism on innovativeness in terms of new product development and commercialization. Similarly, Abdallah and Persson [13] have revealed a positive impact of competitive intensity on innovativeness, whereas Bodlaj and Čater [1] and Uzkurt, Kumar, Kimzan, and Sert [10] have shown no significant impact of competitive intensity on innovativeness. Even worse, Miller and Friesen [3] have demonstrated a positive influence of environmental hostility on innovation, Tajeddini and Trueman [4] have revealed no significant influence of environmental hostility on innovativeness, while Prajogo and McDermott [7] and Alexandrova [11] have shown a negative influence of environmental hostility on innovation and innovativeness, respectively.

Such inconsistencies in these results could be caused by overlooking important moderation or mediation variables that affect the environments-innovation relationships [14]. Moderation involves ascertaining how the strength of the relationship between two variables varies depending on the level of a moderation variable, whereas mediation entails investigating whether the nature of the relationship between two variables is direct or not (i.e., direct or spurious) by identifying a significant intervening mechanism between two variables $[14,15]$. So, to help explain the relationships between environments and innovation better, some researchers have attempted to examine a moderation effect of such variables as entrepreneurial orientation, network density, and the nature of the change on the relationships $[9,16,17]$. For example, AL-Nuiami, Idris, AL-Ferokh, and Joma [16] have investigated a moderation effect of entrepreneurial orientation on the relationship between environmental turbulence (i.e., dynamism, complexity, predictability) and innovation performance. Rodrigo-Alarcon et al. [17] have also examined a moderation effect of network density on the relationship between technological and market dynamism and innovativeness. However, despite the potentially important role of mediators in explaining the relationships between environments and innovation, few researchers have tried to examine an intervening mechanism through which environmental contexts affect firms' innovation, with the exception of Özsomer, Calantone, and Di Benedetto [18], who have examined a mediation effect of strategic posture and organizational structure on the relationship between environmental hostility and innovativeness.

Hence, we attempt to further investigate a mediation effect to clarify the relationships between environments and innovation. In this connection, we propose external knowledge acquisition as an intervening mechanism to link environments with innovation. External knowledge acquisition here is comparable to the dimension of acquisition which is the first of four dimensions of absorptive capacity [19-21]. Based on organizational learning and knowledge-based perspectives [22,23], we argue that external knowledge acquisition is likely to mediate the relationships between environments and innovation. Specifically, we maintain that, faced with dynamic, complex, or hostile environments, firms tend to learn through knowledge acquisition from diverse external sources to cope with their environments effectively and that the external knowledge acquired is expected to become an important resource input for their innovation. In other words, it is argued that increases in environmental dynamism, complexity, and hostility will motivate or prompt firms to acquire more new knowledge from outside, which, in turn, tends to become a critical resource for firms to enhance their ability to innovate.

With this background, we aim to empirically examine a mediation effect of external knowledge acquisition on the relationships between environments (i.e., dynamism, complexity, and hostility) and innovation, and for this purpose, we try to address the following three questions in this research: (1) What effects do environments have on innovation? (2) What effects do environments have on external knowledge acquisition? (3) Does external knowledge acquisition mediate the relationships between environments and innovation?

For data collection and empirical investigation, we relied on an email questionnaire survey of small- and medium-sized Chinese firms in five manufacturing industries. A total of 220 effective data were collected and used in the study. Our results show that dynamism, complexity, and hostility 
have positive effects on innovation and that they also have positive influences on firms' external knowledge acquisition. They further reveal that external knowledge acquisition has a complete mediation effect on the relationships between dynamism and innovation, between complexity and innovation, and between hostility and innovation.

The remaining part of this paper is composed as follows. The next section reviews and discusses the theoretical background of this research, followed by a section explaining a research model and hypotheses on the relationships among environments, external knowledge acquisition, and innovation. The subsequent section explains the methodology of the study, and the following section tests hypotheses and provides the results of this research. The last section presents the conclusions, implications, and limitations of this research with the direction of future research.

\section{Theoretical Background}

\subsection{Environments}

The theory of strategic management argues that environments are critical for organizations to understand for their survival and success, since environments provide a specific context for their operations and behaviors [24]. It is also important to understand that environments are composed of multiple dimensions with varying characteristics, since different environmental dimensions may have a varying influence on organizations' operations and behaviors [3,25]. A review of the literature reveals that dynamism, complexity, and hostility are regarded as three important environmental dimensions [3]. Miller and Friesen [3] identified and utilized these three dimensions to examine the relationships between environments and strategy-making in their research. These environmental dimensions are inherently coherent with the ones identified by Dess and Beard [25]—dynamism, complexity, and munificence, and by Child [26] — variability, complexity, and illiberality. Environmental dynamism refers to the frequency and intensity of environmental changes in technologies, customer needs, products, market demand and others [25]. Environmental complexity means the heterogeneity or diversity of environmental factors, including buyers, suppliers, competitors, and technologies and differentiated products $[25,26]$. Environmental hostility refers to the threat of environments to firms posed by the intensity of unfriendly competition [4]. As such, we focus on these three environmental dimensions to examine their effects on external knowledge acquisition and innovation in further detail in the hypotheses section.

\subsection{Innovation}

Innovation is adopting something new to the organization, including a new product, service, technology, process, policy, plan, program, structure or administrative system [27]. The adoption of innovation is inherently intended to improve organizational effectiveness or performance by creating change in an organization in reaction to or in anticipation of changes in external and internal conditions [28]. Therefore, external environments are expected to have an impact on the adoption of innovation by firms. In this sense, it is not a coincidence to see ample existing studies on the effects of external environments on innovation or innovativeness. For our purpose, innovation and innovativeness are treated as basically equal, since they are closely related in that innovation reflects the outcome of innovativeness, which refers to openness to new ideas as part of a firm's culture [29].

A review of the literature shows that innovation can be classified into the four different types: product innovation, process innovation, market innovation, and management innovation. Schumpeter [30] identifies such innovation types as new products, new production methods, new market exploitation and development, new ways to organize business, and others. This classification is similar to the one introduced by the OECD Oslo Manual [31]: product innovation, process innovation, marketing innovation, and organizational innovation. The two to three different types of innovation identified by other researchers $[32,33]$ can be summarized into the four types mentioned above. In this research, a product innovation refers to a new product or service introduced to meet a market need; a 
process innovation is a new element adopted into a new production or service operation to increase efficiency and quality; a market innovation means a new market or market segment development and a new marketing method employed for the market; and a management innovation is a new managerial and organizational practice introduced into the organization.

\subsection{External Knowledge Acquisition and Mediation Role}

According to the knowledge-based perspective, knowledge is a critical resource to create firms' competitive advantage [23]. Therefore, it is understandable that firms try their best to secure knowledge through both external and internal sources in the processes of organizational learning [22]. However, as competition gets intensified, the product life cycle becomes shorter, and knowledge becomes more widely dispersed as, today [34], firms are inclined to be increasingly more open to the idea of obtaining knowledge externally, as in the case of open innovation [35]. As such, firms today are likely to acquire external knowledge regarding technology, market, and management through such sources as suppliers, buyers, competitors, and alliance partners [36]. Thus, it is expected that acquiring external knowledge is important for firms to improve innovation and performance. Besides, prior research has demonstrated that firms can improve innovation through external knowledge acquisition [37,38]. External knowledge acquisition (EKA) here is defined as an activity in which firms obtain knowledge from external sources.

Moreover, the level of acquiring external knowledge tends to vary depending on the characteristics of environments. For example, when technology- and market-related factors change significantly because of dynamic external environments, firms may need to acquire more external knowledge regarding technologies and markets to be able to respond to these environmental changes more effectively. Similarly, when external environments are more complex and there are more factors to consider in regard to suppliers, customers and competitors, firms are likely to have a greater need to acquire more external knowledge about these factors in response to more complex environments. As such, depending on the characteristics of external environments, firms tend to acquire a different level of external knowledge, which, in turn, is expected to enhance innovation accordingly. Therefore, external knowledge acquisition is expected to play an important mediation role in linking environments with innovation.

\section{Model and Hypotheses}

In the first subsection, this study theorizes the effects of environments on innovation, based on the first research question. In the second subsection, the study further theorizes the effects of environments on external knowledge acquisition by addressing the second research question. In the last subsection, this research theorizes the mediation effect of external knowledge acquisition on the relationships between environments and innovation by tackling the last question. All the hypotheses included in the study are summarized in the theoretical model, as presented in Figure 1.

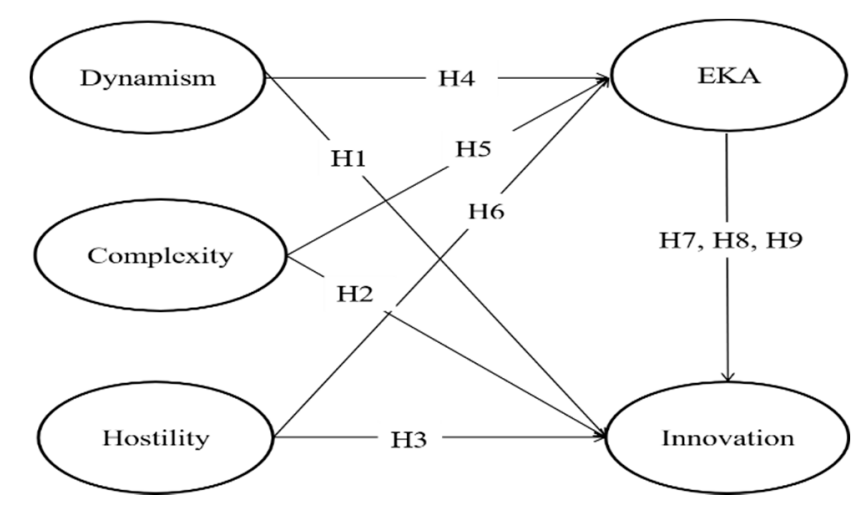

Figure 1. Theoretical Model. 


\subsection{Effects of Environments on Innovation}

\subsubsection{Environmental Dynamism}

Environmental dynamism relates to how frequent environmental changes are for firms [25,26]. Specifically, environmental dynamism comes from the changes in technologies, customer needs, products and services, market demand, and competitors' strategic behavior [17]. When environments become more dynamic, firms are likely to be motivated or forced to behave more proactively by taking risks to deal with changes in technologies, customer needs, markets, and others more effectively [39]. Bettis and Hitt [40] also argue that, when firms experience such environmental changes as a shorter product life cycle and a shift in technology and market, pursuing a new product and technology development becomes critical for their survival and success. In addition, when firms experience competitors' rapid behavioral changes, their existing resources and capabilities may become obsolete and, to mitigate this threat of obsolescence, firms need to be more innovative and introduce new products, services, and markets more proactively by continuously upgrading their resources and capabilities [41]. Furthermore, environmental dynamism tends to enhance firms' entrepreneurial orientation, which leads to their increased innovation [42]. Steve Jobs' commitment to innovation and risk-taking is a great example of the outcome of the strong entrepreneurship orientation. Apple has been successful in increasing customer satisfaction through innovative products in response to the changes in customer needs. Besides, there is empirical evidence that environmental dynamism has a positive influence on innovation $[1,8,17]$. Hence, it is expected that environmental dynamism is positively related with innovation.

Hypothesis 1. Environmental dynamism has a positive relationship with innovation.

\subsubsection{Environmental Complexity}

Environmental complexity has to do with how heterogeneous or diverse environmental the factors which firms must deal with are $[25,26]$. Environmental complexity increases with the number of competitors, the diversity of buyers and suppliers, the existence of differentiated products, and the diversity of technologies [25]. Therefore, operating in more complex environments, firms are likely to face more diverse factors of environments, which enhance the demand for their strategic activities with respect to technologies, products, markets, suppliers, and competitors [3]. To meet this demand by heterogeneous environments more effectively, firms need to be more innovative in developing diverse technologies, products, markets, and management processes and systems [43]. It seems logical to expect that firms need to have the ability to adopt something new to the organization to effectively cope with the diverse needs of heterogeneous factors of environments. Furthermore, prior research has shown empirical evidence of a positive influence of environmental complexity on innovation or innovativeness $[3,4,44]$. For example, in a large-scale study of the impact of environmental complexity on firms' behavior conducted by KPMG in 2010 with senior executives of large companies across various industry sectors in twenty-two countries, environmental complexity has been found to be closely correlated with technological innovation. Specifically, more than eighty percent of the executives have identified the need to develop new skills as their primary challenge resulting from environmental complexity. Based on the discussion above, it is expected that environmental complexity is positively related with innovation.

Hypothesis 2. Environmental complexity has a positive relationship with innovation. 


\subsubsection{Environmental Hostility}

Environmental hostility relates to how serious threats to firms are posed by various unfavorable external conditions, including competitive intensity, industry structure, governmental regulations, and limited resources [45]. Similarly, Potter [46] maintains that environmental threats to firms can come from such conditions as the degree of competitive intensity, the randomness of competitors' behavior, the industry growth rate, the access to necessary inputs, and the availability of product-market opportunities. With regard to its effect on innovation, environmental hostility tends to have both positive and negative influences on innovation or innovativeness for firms [2]. Some researchers have argued that, in hostile environments, where firms encounter various challenges characterized by intense competition, resource scarcity and others, they may still be motivated or forced to enhance their innovative capability to cope with and adapt to those environmental challenges $[4,11]$. For instance, faced with increased environmental hostility triggered by the recent COVID-19 pandemic and intensive competition, Samsung Electronics has made the largest ever investment in R\&D in the first quarter of the year 2020 in order to widen the gap with competitors [47]. On the contrary, other researchers have claimed that, in hostile environments, where firms are faced with severe competition, scarcer resources, and thinner profit margins, they may try harder to conserve resources and pursue economical strategic approaches more selectively by avoiding extensive experimentation, risk taking, and proactiveness that can be harmful in threatening environments [3]. Based on the discussion above, we propose two competing hypotheses, as follows.

Hypothesis 3a. Environmental hostility has a positive relationship with innovation.

Hypothesis 3b. Environmental hostility has a negative relationship with innovation.

\subsection{Effects of Environments on External Knowledge Acquisition}

\subsubsection{Environmental Dynamism}

Environmental dynamism represents the changes in environmental factors, such as technologies, competitors, customers, suppliers, and markets [3]. The changes in these factors tend to give rise to environmental uncertainties for firms [25], since firms lack knowledge regarding changing environmental factors. Therefore, increased environmental uncertainties are likely to enhance the need for new knowledge, thereby urging firms to obtain new knowledge about the state of changing environmental factors, the effect of these environmental factors on firms, and the response firms can make to address these environmental factors [48]. In this regard, firms will have to secure a diverse set of knowledge to effectively cope with the uncertainties caused by environmental changes. However, it is practically impossible for firms to secure all the necessary knowledge internally, so firms will have to obtain knowledge externally through their interactions with various sources, including competitors, suppliers, buyers, consultants, research institutes, and alliance partners [35]. For example, when a new technology appears in an industry, firms needs to acquire new knowledge from external sources to understand its state, its effect on firms, and the response options available to firms to cope with it more effectively. Hence, it is expected that environmental dynamism tends to increase firms' external knowledge acquisition.

Hypothesis 4. Environmental dynamism has a positive relationship with external knowledge acquisition.

\subsubsection{Environmental Complexity}

Environmental complexity comes from heterogeneous or diverse environmental factors in an industry $[3,26]$. This suggests that operating in more complex environments, firms will encounter more diverse technologies, competitors, buyers, suppliers, and markets and have a greater number of environmental elements to deal with [25]. So, the increased diversity of environmental factors 
will necessarily raise environmental uncertainties for firms to deal with, and the firms faced with increased environmental uncertainties will have greater needs to acquire knowledge about diverse environmental factors [49]. Hence, firms under more complex environments will have to obtain more knowledge about diverse environmental factors through various sources to cope with them effectively. For instance, when technologies or inputs to production are more complex in an industry, firms are likely to be required to acquire more knowledge about diverse technologies and inputs from competitors, suppliers, or other sources to understand them better before responding to them. Therefore, environmental complexity is expected to increase firms' external knowledge acquisition.

\section{Hypothesis 5. Environmental complexity has a positive relationship with external knowledge acquisition.}

\subsubsection{Environmental Hostility}

Environmental hostility has to do with the environmental threats to firms caused by various unfavorable external conditions, which include competitive intensity, competitors' random behavior, adverse industry growth, governmental regulations, limited access to inputs and resources $[3,45]$. These unfavorable and adverse external conditions can certainly cause high environmental uncertainties to firms, and the firms with such environmental uncertainties are likely to have greater needs to find out more about their environments to reduce the uncertainties. Therefore, the firms operating in hostile environments seem to be motivated to acquire more external knowledge about their environments through various sources to deal with them effectively [46]. For example, when the price competition (as a sign of environmental hostility) is prevalent in an industry, a company tends to be motivated to find out more about competitors' cost positions, the ways competitors achieve better cost positions, if better at all, alternative ways to source low-cost inputs, and alternative cost-effective approaches to marketing and sales through external sources like competitors, suppliers, buyers, and consultants to cope with the adverse situation efficiently and effectively. Based on the discussion above, it is proposed that environmental hostility is likely to enhance firms' external knowledge acquisition.

Hypothesis 6. Environmental hostility has a positive relationship with external knowledge acquisition.

\subsection{Mediation Effects of External Knowledge Acquisition}

The literature provides evidence that external knowledge acquisition can contribute to the enhancement of firms' innovation [50]. Firms can certainly acquire a diverse set of both tacit and explicit knowledge with regard to technology, market, and management through competitors, suppliers, buyers, research institutes, and consultants and through interactive, social, and connected processes with alliance or network partners [50]. This diverse set of knowledge acquired externally can be utilized as valuable inputs into the processes of innovation in terms of product, process, market and management, thereby improving firms' innovation.

Furthermore, the previous section argues that environments, in terms of dynamism, complexity and hostility, tend to have influence on external knowledge acquisition, and the section above argues that increased external knowledge acquisition is expected to enhance innovation. These two arguments combined seem to suggest that, faced with dynamic, complex or hostile environments, firms tend to acquire knowledge from external sources to deal with their environments more effectively, and the external knowledge acquired is likely to serve as a critical resource for improving firms' innovation. Thus, it is proposed here that external knowledge acquisition will mediate the relationships between environments and innovation. Specifically, operating in more dynamic environments, firms are likely to acquire more new knowledge about their changing environments from external sources, and the new external knowledge acquired, in turn, is expected to become an important resource input into the innovation processes. Similarly, faced with more complex environments with a greater number of factors to consider, firms are likely to obtain more external knowledge regarding these factors through 
suppliers, competitors, and buyers to respond to them effectively, and the new knowledge acquired externally is apt to be utilized as an essential resource to enhance innovation. In addition, operating in more hostile environments, firms tend to be motivated to acquire more new knowledge about how to deal with unfavorable conditions like severe competition, limited resources and others, and the new external knowledge acquired is expected to become a critical resource necessary for improving innovation. Based on the discussion above, the following hypotheses are proposed:

Hypothesis 7. External knowledge acquisition mediates the relationship between environmental dynamism and innovation.

Hypothesis 8. External knowledge acquisition mediates the relationship between environmental complexity and innovation.

Hypothesis 9. External knowledge acquisition mediates the relationship between environmental hostility and innovation.

\section{Methodology}

\subsection{Sample and Data Collection}

To test our hypotheses, we collected data through an email questionnaire survey from small- and medium-sized manufacturing firms headquartered in Beijing, China. We targeted five manufacturing industries, including food, textile and garment apparel, chemical raw materials and chemical, special equipment, and computer/communication/other electronic equipment, with varying environmental characteristics. Following the Notice on Printing and Distributing the Stipulation Standards for SMEs jointly issued by the National Bureau of Statistics and the Ministry of Finance in China, we focused on firms with employees ranging from less than 1000 to 20. Based on this criterion, a total of 1936 companies in five industries were identified from the 2018 Beijing Enterprise Yellow Pages. Out of these, 283 firms were dropped in the process of confirming their contact information and of asking for participating in the survey by phone calls and, finally, 1653 firms remained as the effective target population of this study. In addition, since this research required a general management perspective on external environments, external knowledge acquisition and innovation, the heads of these firms were targeted as potential respondents for our survey.

We developed a survey questionnaire based on the literature. It was professionally translated into Chinese and back into English to ensure conceptual equivalence. Then, an interview-based pretest of the questionnaire was conducted with the four Chinese senior executives of SMEs in the relevant industries to assess the clarity and appropriateness of the questions and the respondents' ability to answer the questions. The questionnaire was further revised based on their feedback. The finalized questionnaire was emailed with an online link to the heads of effective target population three times with intervals of two weeks, followed by phone calls each time to ask for their participation in the survey. Personal visits were also made to the relevant firms for survey responses when necessary. This resulted in a total of 242 responses and, after significantly incomplete and insincerely filled-out surveys were dropped, 220 usable surveys remained, with an effective response rate of 13.3 percent. This response rate is comparable to that of many previous studies [1].

To test for non-response bias, we compared the two groups of early and late responses, following Bodlaj and Cater [1]. Early responses were the ones received from the first round of invitation emails, and late responses were the ones received from the second and third rounds of invitation emails. No significant differences were observed between these two groups in terms of industry $(p=0.230)$, employees $(p=0.376)$, and total sales $(p=0.396)$, thereby suggesting that there was no potential non-response bias in our study.

Furthermore, since our study relied on a single respondent to collect data for measuring both independent and dependent variables at the same time, we checked for common method bias [51]. 
To test for this potential bias in our study, Harman's one-factor test was applied through a principal components analysis of all the constructs included in our study, as suggested by Podsakoff and Organ (1986) [52]. This analysis resulted in eight factors with eigenvalues greater than 1.0, explaining $65.35 \%$ of the variance, whereas the first factor accounted for only $25.99 \%$ of the variance, far less than $50 \%$, a cut-off point suggested by Podsakoff and Organ (1986) [52]. Therefore, it was concluded that there was little threat of notable common method bias.

The respondents had their current positions of Presidents (22.3\%), Vice Presidents/Directors (17.7\%), Functional Managers (36.8\%) and Assistant Managers and below (23.2\%), and they had been in their current positions for about five years on average. In our sample, firms in food, textile, chemical, special equipment, and computer/communication/electronics industries account for $15.9 \%, 20.0 \%$, $14.1 \%, 20.5 \%$, and $29.5 \%$, respectively. Firms with employees of 20-49, 50-99, 100-299, and 300-999 accounted for $50.4 \%, 20.4 \%, 13.2 \%$, and $12.7 \%$, respectively. Additionally, the average number of years of operation for our sample firms was about 15 . Overall, our sample firms seemed to be relatively small and young in the sense that the majority of our sample firms had less than 100 employees $(70.8 \%)$ and less than 20 years of business experience $(77.8 \%)$.

\subsection{Measurement}

\subsubsection{Environmental Dynamism}

We measured environmental dynamism with a four-item scale that we modified from Fuentes-Fuentes et al. [53], and $\mathrm{Li}$ and Liu [54]. The scale was designed to primarily capture the changes in environmental factors. Specifically, the question items included in this scale were: "products in our industry become outdated very quickly"; "the tastes and preferences of customers in our industry change very quickly"; "the rate of change in market activities of our competitors is very high"; and "product technologies in our industry change very quickly". For this measure, respondents were asked to indicate $(1=$ "strongly disagree" to $7=$ "strongly agree" $)$ the extent to which they agree or disagree with each statement, based on the industry where their major business operates.

\subsubsection{Environmental Complexity}

We adapted the measure of environmental complexity from Fuentes-Fuentes et al. [53], Sutcliffe and Huber [55], and Newkirk and Lederer [56]. The measure was intended to cover the diversity of various environmental factors. To measure this variable, respondents were asked to indicate $(1=$ "strongly disagree" to $7=$ "strongly agree") the extent to which they agree or disagree with each of the following statements, based on the industry where their major business operates: "firms in our industry deal with very diverse types of customers"; "firms in our industry interact with a large number of different organizations in the production and distribution of products"; "products in our industry must reflect very diverse market needs"; and "the tastes and preferences of customers are very heterogeneous".

\subsubsection{Environmental Hostility}

Environmental hostility was measured with a four-item scale modified from Khandwalla [57] and Slevin and Covin [58]. The scale was intended to capture the threatening or unfavorable environmental conditions. For this scale, we used the following question items: "it is very difficult to find opportunities for growth in our industry"; "firms in our industry face various environmental elements threatening survival"; "our competitors' strategic actions are very hostile"; and "firms in our industry are threatened by tough competition". To measure this variable, we asked respondents to indicate $(1=$ "strongly disagree" to 7 = "strongly agree") the extent to which they agree or disagree with each statement, based on the industry where their major business operates. 


\subsubsection{External Knowledge Acquisition}

We adapted the measure of external knowledge acquisition from Bojica and Fuentes [59] and $\mathrm{Li}$, Liu, and Liu [60]. Based on these previous studies, this measure focused on acquiring external knowledge on the areas of technology, market/industry, and management. To measure this variable, we asked respondents to indicate ( $1=$ "not at all acquired" to $7=$ "extensively acquired"), based on their major business, the extent to which their company acquires knowledge about each of the following items from external sources: "external knowledge about technology", "external knowledge about product development", "external knowledge about operations and production processes", "external knowledge about the market and industry", and "external knowledge about management (management systems/practices, etc.)".

\subsubsection{Innovation}

Based on prior research [33], innovation was operationalized as a second-order factor which comprises four first-order indicators: product innovation, process innovation, market innovation, and management organization. We adapted the measures of these four innovation types from Liao et al. [32], Wang and Ahmed [33]. These respective measures were designed to capture a new product introduced to the market, a new element adopted into a new production process, a new market development and a new marketing method employed, and a new managerial and organizational practice introduced. For these measures, respondents were asked to indicate $(1=$ "strongly disagree" to $7=$ "strongly agree") the extent to which they agree or disagree with each of the statements, based on their major business. The measurement items are provided in Appendix B.

\subsubsection{Control Variables}

We included industry type, firm size, and firm age in our model to control their effects on external knowledge acquisition and innovation. Firms operating in high-tech industries may be more motivated to pursue external knowledge acquisition and innovation than others, since high-tech firms are more likely to face uncertain environments than low-tech firms, so we controlled for industry type and coded high-tech industries as " 1 " and others as " 0 " [11]. In addition, larger firms are likely to have more resources and capabilities to engage in external knowledge acquisition and innovation than smaller ones, so we also controlled for firm size and measured it by the number of employees [61]. Similarly, since older firms tend to have more experience in acquiring external knowledge and participating in innovation than younger ones, firm age was further controlled for and was measured by the number of years of operation [62].

\section{Analyses and Results}

\subsection{Method of Analyses}

AMOS 25 was used to test the measurement model and the theoretical model based on the structural equation modeling. To test the hypothesized mediation relationships, we employed Holmbeck's [63] guideline for testing for mediation using SEM. The bootstrap confidence interval approach was also applied to test the statistical significance of indirect effects [15]. In doing so, we calculated the lower limit (LLCI) and upper limit (ULCCI) of a 95\% bootstrap confidence interval for indirect effects, using 5000 bootstrap samples.

\subsection{Measurement Model}

Reflective measurement models were used in our study. All the latent variables in our study were measured or modeled as first-order factors, except for innovation that was measured as a second-order factor. To assess the reliability and validity of our measurement model, we conducted a confirmatory factor analysis on the previously established scales with following criteria: factor loading, 
Chronbach's Alpha, average variance extracted (AVE) composite reliability (CR), and discriminant validity. As shown in Table 1, all the items loaded on their respective factors with factor loadings greater than the cutoff value of 0.60 [64]. The results of the reliability test for the constructs shown in Table 1 also confirmed the satisfactory levels of convergent validity that exceed the minimum cutoff values of above 0.5 for the average variance extracted (AVE), above 0.7 for composite reliabilities (CR) [65], and above 0.7 for Chronbach's Alphas [66], respectively. The discriminant validity of the constructs was further tested by the inter-construct correlation matrix in Table 2, where the square root of AVE for each factor was greater than any of its correlations with the other factors, confirming adequate discriminant validity for all the first and second-order factors [67]. As Table 1 shows, the goodness-of-fit results for our CFA model revealed an acceptable level of fit with the covariances provided by the dataset, with $\chi^{2}=1001.687, \mathrm{df}=651, p<0.001, \chi^{2} / \mathrm{df}=1.539$, TLI(NNFI) $=0.903$, $\mathrm{CFI}=0.910$, RMSEA $=0.050[64,68]$.

Table 1. Measurement model results.

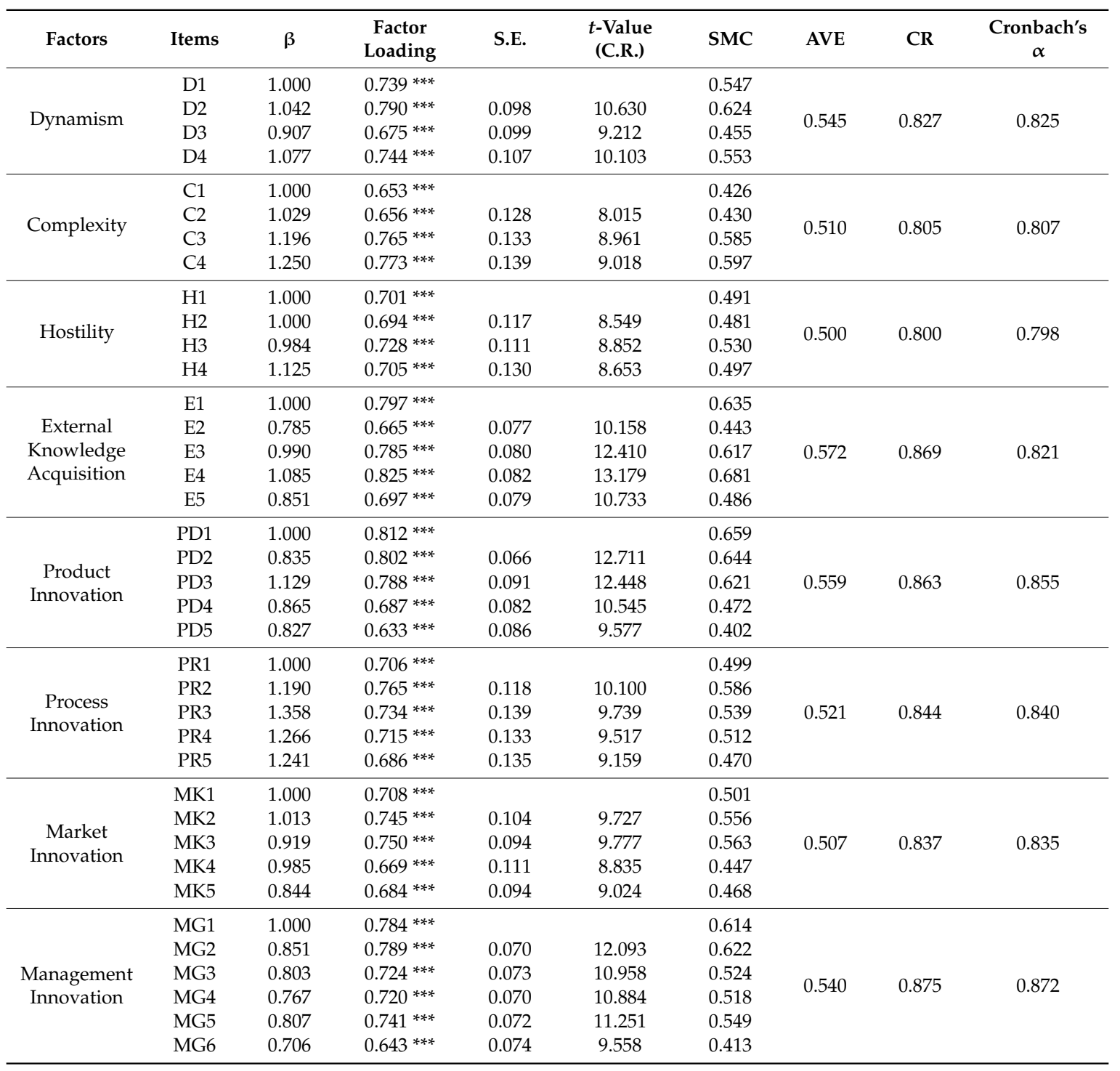


Table 1. Cont.

\begin{tabular}{ccccccccc}
\hline Factors & Items & $\beta$ & $\begin{array}{c}\text { Factor } \\
\text { Loading }\end{array}$ & S.E. & $\begin{array}{c}t \text {-Value } \\
\text { (C.R.) }\end{array}$ & SMC & $\begin{array}{c}\text { AVE } \\
\text { CR }\end{array}$ & $\begin{array}{c}\text { Cronbach's } \\
\alpha\end{array}$ \\
\hline \multirow{2}{*}{ Innovation } & PD & 1.000 & $0.691^{* * *}$ & & & 0.477 & \\
& $\mathrm{MG}$ & 1.265 & $0.723^{* * *}$ & 0.186 & 6.797 & 0.522 & 0.501 & 0.800 \\
& $\mathrm{MK}$ & 0.921 & $0.640^{* * *}$ & 0.153 & 6.024 & 0.410 & 0.764 \\
& $\mathrm{PR}$ & 0.879 & $0.772^{* * *}$ & 0.132 & 6.645 & 0.596 & \\
\hline
\end{tabular}

Note: $t$-values for $\mathrm{n}=220$ subsamples; $\mathrm{CR}$, composite reliability; SE, standard error; AVE, average variance extracted. $* * * \leq 0.001$.

Table 2. Inter-construct correlation matrix.

\begin{tabular}{lccccccc}
\hline & Mean & SD & $\mathbf{1}$ & $\mathbf{2}$ & $\mathbf{3}$ & $\mathbf{4}$ & $\mathbf{5}$ \\
\hline 1. Dynamism & 4.798 & 1.428 & $(0.738)$ & & & & \\
2. Complexity & 4.641 & 1.322 & $0.583^{* * *}$ & $(0.714)$ & & & \\
3. Hostility & 4.341 & 1.452 & $0.357^{* * *}$ & 0.140 & $(0.707)$ & & \\
4. EKA & 4.438 & 1.406 & $0.600^{* * *}$ & $0.615^{* * *}$ & $0.441^{* * *}$ & $(0.756)$ & \\
5. Innovation & - & - & $0.466^{* * *}$ & $0.408^{* * *}$ & $0.375^{* * *}$ & $0.690^{* * *}$ & $(0.708)$ \\
\hline
\end{tabular}

Note: Diagonal elements (in parenthesis) are the square root of AVE; off-diagonal elements are the correlations among constructs in the inner model. $* * * p \leq 0.001$.

\subsection{Structural Model}

We adopted Holmbeck's [63] guideline to test the hypothesized mediation effects. Based on Baron and Kenny's [69] causal step approach, Holmbeck [63] proposes a guideline to examine mediation effects through sequential goodness-of-fit and significance tests for the three structural models in the following steps. The first step is to test the direct effect model where mediators (M) are not included. At this point, the model should provide an adequate fit with a significant direct effect of independent variables $(X)$ on dependent variables $(Y)$ [63]. The next step is to test the complete mediation model as a baseline in which X-Y path is constrained to zero, given that the direct effect model is consistent with the data or meets the criteria given above. As in the direct effect model, the model should fit the data well and both X-M and M-Y path coefficients must be significant in the directions predicted. The final step in assessing a mediation effect is to compare the difference in model fits between the baseline (complete mediation) model and the partial mediation model where the direct path from $X$ to $\mathrm{Y}$ is not constrained to zero. If the partial mediation model cannot provide a significant improvement in fit over the complete mediation model, namely, if the addition of X-Y path to the baseline model does not improve fit, complete mediation effect can be confirmed empirically. Improvement in fit can be assessed with a chi-square difference test using chi-square values and degrees of freedom from two nested models. Therefore, if the difference between chi-square statistics for two models is not significant, a complete mediation model should be employed. However, if the difference between chi-square statistics for the two models is significant, which implies that the partial mediation model significantly improves fit, there exists a partial mediation effect in the theoretical model. In this case, the direct path between $X$ and $Y$ with $M$ controlled should be significant, with a smaller path coefficient in absolute value than that in the direct effect model $[63,65]$.

The guideline by Holmbeck [63] provides the following advantages in testing mediation effect based on the structural equation modeling approach. First, it allows researchers to determine a proper form of mediation model a priori through the comparison of different goodness-of-fit tests for the two mediation models so that they can avoid the potential problems of over- and under-estimation of mediation effects. Second, although there are some studies advocating indirect effects with no causal relationship between $\mathrm{X}$ and $\mathrm{Y}$ anticipated, complete or partial mediation can be defined only when a researcher has determined that the total effect is different from zero [15]. Hence, the guideline or method is particularly useful for the studies that need to first establish that $X$ exerts a direct effect on $Y$ and then investigate a specific mechanism by which the effect of $X$ is transferred to $Y$. 
To examine a possible mediation role of external knowledge acquisition in our research, we tested the following three structural models based on the guideline offered by Holmbeck [63]. Model 1 is the direct effect model to establish the effect of dynamism, complexity and hostility on innovation, Model 2 is the complete mediation model in which X-Y path is set to zero, and Model 3 is the partial mediation model that represents hypothesized relationships. Path coefficients and their significance levels, along with the R2 values, for each of the endogenous constructs, are shown in Figure 1 for the direct effect model (Model 1), in Figure 2 for the complete mediation model (Model 2), and in Figure 3 for the partial mediation model (Model 3).

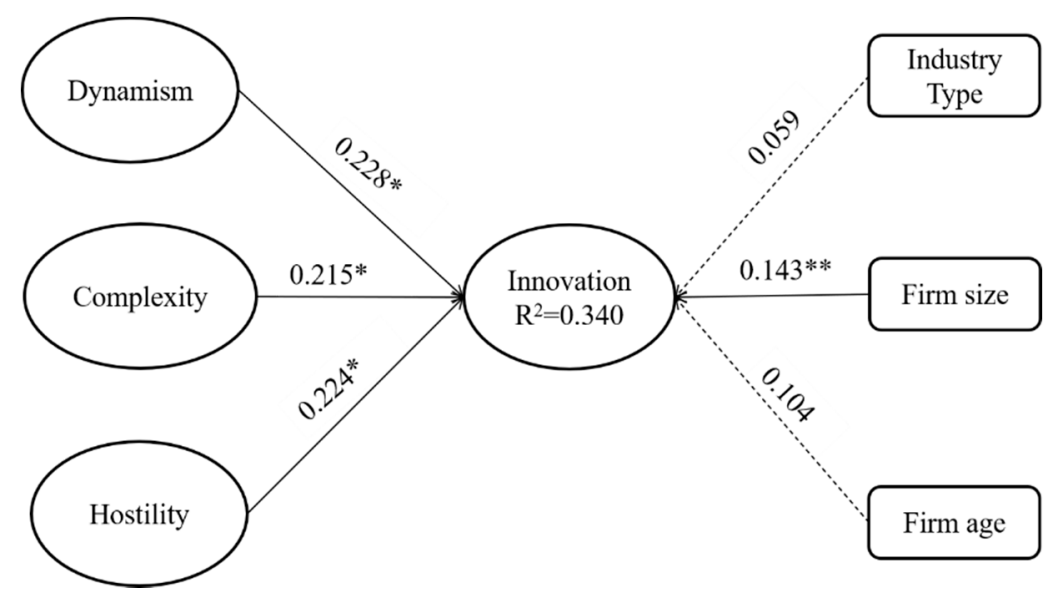

Figure 2. Direct effect model (Model 1). Note: $* p \leq 0.05 . * * \leq 0.01$.

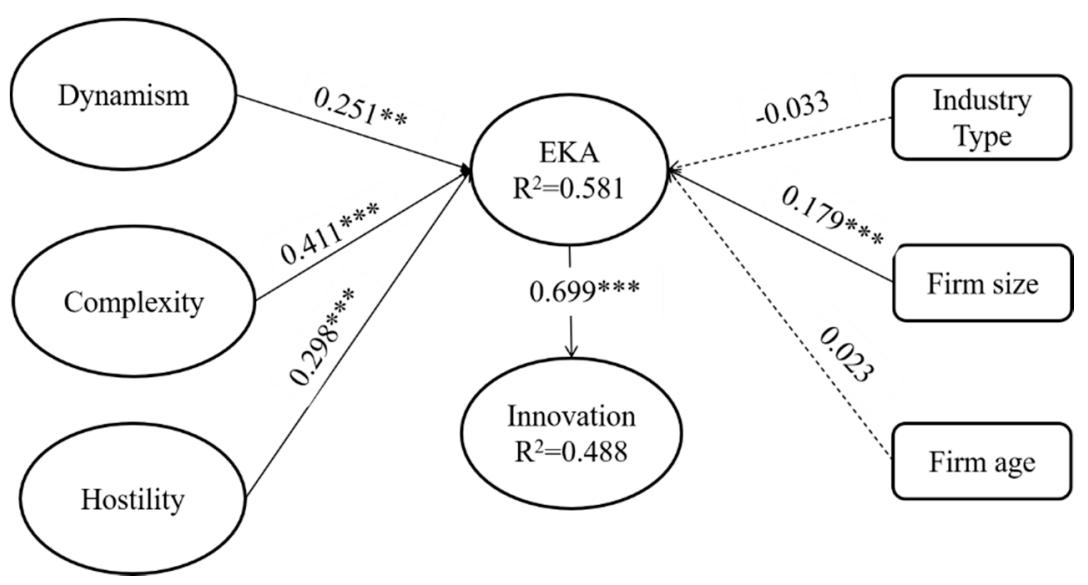

Figure 3. Complete mediation model (Model 2). Note: $* * p \leq 0.01 . * * * \leq 0.001$.

As reported in Table 3, Model 1 (direct effect model) indicates an acceptable level of fit despite a relatively low TLI index $\left(\chi^{2}=868.496, \mathrm{df}=572, p<0.001, \chi^{2} / \mathrm{df}=1.518, \mathrm{CFI}=0.909\right.$, TLI $=0.899$, RMSEA $=0.049$ ) [70]. Furthermore, the model yielded significant results for the hypothesized relationships between dynamism and innovation $(\beta=0.228, p<0.05)$, between complexity and innovation $(\beta=0.215$, $p<0.05)$ and between hostility and innovation $(\beta=0.224, p<0.05)$, thereby supporting Hypotheses 1 , 2 , and 3a, respectively (see Figure 2 and Table 3). Notably, a positive, rather than negative, relationship between hostility and innovation was revealed in the study, and this result was consistent with that of some previous studies [3,11]. Additionally, we found that among the control variables, only firm size played a significant role in affecting innovation, while firm age and industry type had no significant effect on innovation. 
Table 3. Mediation analysis and model fit comparison.

\begin{tabular}{|c|c|c|c|}
\hline & $\begin{array}{c}\text { Direct Effect Model } \\
\text { (Model 1) } \\
S \cdot \beta(t \text {-Value) }\end{array}$ & $\begin{array}{c}\text { Full Mediation Model } \\
\text { (Model 2) } \\
\text { S. } \beta \text { ( } t \text {-Value) }\end{array}$ & $\begin{array}{c}\text { Partial Mediation } \\
\text { Model } \\
\text { (Model 3) } \\
S \cdot \beta(t \text {-Value) }\end{array}$ \\
\hline \multicolumn{4}{|l|}{ Path } \\
\hline DN-INN & $0.228(2.018) *$ & & $0.078(0.732)$ \\
\hline CM-INN & $0.215(2.044) *$ & & $-0.037(-0.328)$ \\
\hline HS-INN & $0.224(2.455)$ * & & $0.046(0.508)$ \\
\hline DN-EKA & & $0.251(2.822)^{* *}$ & $0.244(2.712)^{* *}$ \\
\hline CM-EKA & & $0.411(4.749)^{* * *}$ & $0.419(4.774)^{* * *}$ \\
\hline HS-EKA & & $0.298(4.076)^{* * *}$ & $0.296(4.003)^{* * *}$ \\
\hline EKA-INN & & $0.699(6.877)^{* * *}$ & $0.612(4.491)^{* * *}$ \\
\hline Firm age-INN & $0.104(1.456)$ & & $0.094(1.425)$ \\
\hline Firm size-INN & $0.143(2.005) * *$ & & $0.035(0.515)$ \\
\hline Industry type-INN & $0.059(0.829)$ & & $0.085(1.269)$ \\
\hline Firm age-EKA & & $0.023(0.410)$ & $0.012(0.212)$ \\
\hline Firm size-EKA & & $0.179((3.229) * * *$ & $0.177(3.144)^{* *}$ \\
\hline Industry type-EKA & & $-0.033(-0.591)$ & $-0.043(-0.758)$ \\
\hline \multicolumn{4}{|l|}{$R^{2}$} \\
\hline INN & 0.340 & 0.488 & 0.502 \\
\hline EKA & & 0.581 & 0.574 \\
\hline \multicolumn{4}{|l|}{ Model Fit } \\
\hline$x^{2}$ & $868.496^{* * *}$ & $1091.417^{* * *}$ & $1085.081^{* * *}$ \\
\hline $\mathrm{df}$ & 572 & 756 & 750 \\
\hline$\chi^{2} / \mathrm{df}$ & 1.518 & 1.444 & 1.447 \\
\hline CFI & 0.909 & 0.915 & 0.915 \\
\hline TLI & 0.899 & 0.907 & 0.907 \\
\hline RMSEA & 0.049 & 0.045 & 0.045 \\
\hline
\end{tabular}

Note: $* p \leq 0.05 . * * p \leq 0.01 . * * * \leq 0.001$.

The fit indices of Model 2 (complete mediation model) $\left(\chi^{2}=1091.417, \mathrm{df}=756, p<0.001\right.$, $\left.\chi^{2} / \mathrm{df}=1.444, \mathrm{CFI}=0.915, \mathrm{TLI}=0.907, \mathrm{RMSEA}=0.045\right)$, as shown in Table 3, suggested a better fit to the data. Model 2 also indicated that dynamism $(\beta=0.251, p<0.01)$, complexity $(\beta=0.411$, $p<0.001)$, and hostility $(\beta=0.298, p<0.001)$ were all positively associated with external knowledge acquisition, together with the R2 index of the endogenous latent variables, innovation (0.488) and EKA (0.581), which were much higher than the required minimum of 0.1 recommended by [71]. Therefore, Hypotheses 4, 5, and 6 were supported. In addition, the path coefficient from external knowledge acquisition to innovation is also positive and significant $(\beta=0.699, p<0.001)$ (see Figure 3 and Table 3 ).

As a final step, we conducted a chi-square difference test for Model 2 (complete mediation model) and Model 3 (partial mediation model) to determine a proper form of mediation model that better explains the hypothesized relationships. Given that the difference in the degrees of freedom between the two models was 6 , it was concluded that the difference in chi-square value between the two was statistically insignificant $(\Delta=6.336, p>0.05)$. Therefore, we were able to confirm that the hypothesized mediation relationships in our study were all intrinsically complete. Moreover, in Model 3 (partial mediation model $)\left(\chi^{2}=1085.081, \mathrm{df}=750, p<0.001, \chi^{2} / \mathrm{df}=1.447, \mathrm{CFI}=0.915\right.$, TLI $=0.907$, RMSEA $=0.045)$, we found that the previously positive and significant path coefficients from dynamism, complexity, and hostility to innovation were all reduced to non-significance after controlling for the effect of external knowledge acquisition on innovation (see Figure 4). These findings suggest that external knowledge acquisition completely mediates the relationships between three respective environmental dimensions and innovation. 


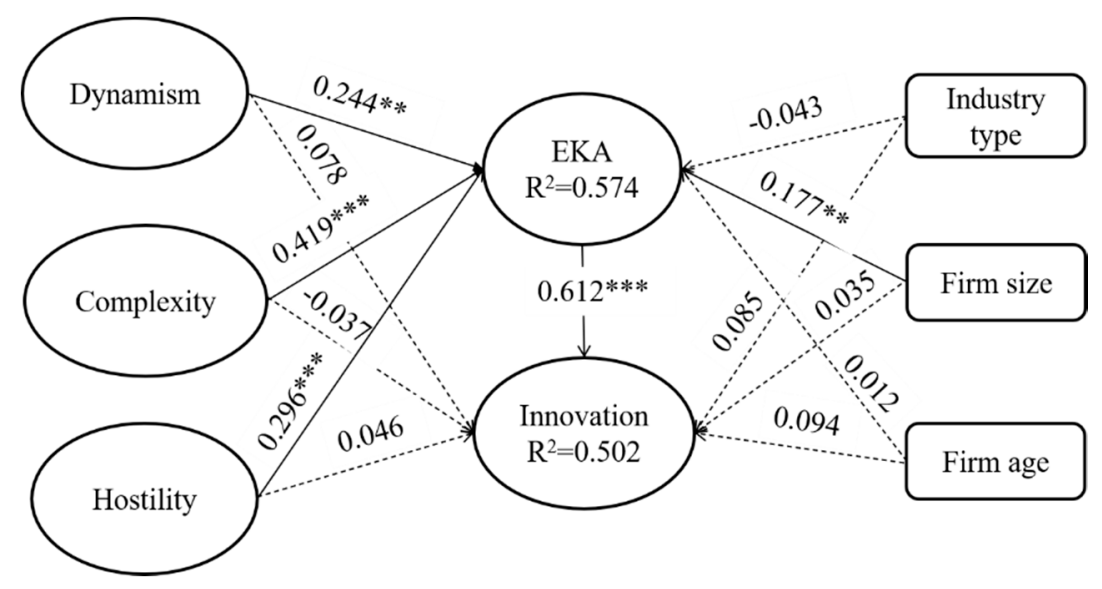

Figure 4. Partial mediation model (Model 3). Note: $* * p \leq 0.01 . * * * \leq 0.001$.

Additionally, to test the statistical significance of indirect effects, we applied the bootstrap confidence interval approach suggested by Hayes [15]. We calculated the lower limit (LLCI) and upper limit (ULCCI) of a 95\% bootstrap confidence interval for indirect effects, using 5000 bootstrap samples. As reported in Table 4 , the indirect effects of dynamism $(\beta=0.175, C I=0.044-0.298)$, complexity $(\beta=0.287, C I=0.171-0.411)$, and hostility $(\beta=0.208, C I=0.101-0.325)$ on innovation through external knowledge acquisition were all positive and significant. Thus, Hypotheses 7,8 , and 9 were finally supported.

Table 4. Bootstrap significance test for indirect effects in Model 2.

\begin{tabular}{llcccc}
\hline \multirow{2}{*}{ Path } & \multirow{2}{*}{ S· $\boldsymbol{\beta}$} & \multirow{2}{*}{ Boot SE } & \multicolumn{2}{c}{ Boot 95\% CI } \\
\cline { 5 - 6 } & & & & LLCI & ULCI \\
\hline \multirow{3}{*}{ Indirect effect } & DN-INN & 0.175 & 0.065 & 0.044 & 0.298 \\
& CM-INN & 0.287 & 0.062 & 0.171 & 0.411 \\
& HS-INN & 0.208 & 0.056 & 0.101 & 0.325 \\
\hline
\end{tabular}

\section{Conclusions and Discussion}

\subsection{Conclusions}

Researchers have paid a lot of attention to investigating the relationships between environments in terms of dynamism, complexity, and hostility and innovation or innovativeness $[1,2,6,18]$. However, the results of previous research seem to be rather incoherent and, to clarify the relationships between environments and innovation, we have proposed external knowledge acquisition as an intervening mechanism to link them and investigated its mediation effect on the relationships. We have argued that increased environmental dynamism, complexity, and hostility are likely to push firms to acquire more external knowledge, which can serve as a valuable resource input to improve firms' innovation.

The key conclusions of the study are as follows. First, all three respective environmental dimensions - dynamism, complexity, and hostility - have positive total effects on innovation before the effect of external knowledge acquisition is controlled for. That is, increased environmental dynamism, complexity, and hostility seem to motivate or lead firms to adopt more innovations in terms of product, process, market and management to cope with their environments more effectively when external knowledge acquisition as a mediator is not considered. Second, environmental dynamism, complexity, and hostility have all positive influences on firms' acquiring external knowledge. As environments become more dynamic, complex, and hostile, firms are likely to acquire more new knowledge from external sources to deal with their environments better. Third, external knowledge acquisition has a positive impact on innovation, and this suggests that, as firms acquire more new knowledge from 
external sources, they tend to improve their ability to innovate by utilizing external knowledge acquired as their critical resource input in the process of innovation. Fourth, the relationships between dynamism and innovation, between complexity and innovation, and between hostility and innovation are all completely mediated by external knowledge acquisition. Namely, dynamism, complexity, and hostility all have strong indirect positive effects on innovation through external knowledge acquisition, and the direct positive effects that three respective environmental dimensions have on innovation disappear completely after controlling for the effect of external knowledge acquisition.

These findings suggest the importance of open innovation for firms operating in dynamic, complex and hostile environments, and these findings appear to be consistent with those of previous studies on open innovation that refers to innovation through learning from others beyond organizational boundaries by building collaboration networks with external partners. According to the open innovation literature, the degree of openness in firms' innovation depends on various environmental dimensions or factors [72], which tend to motivate firms to rely more on external knowledge for their innovation, such as technological and market turbulence [73,74], competition intensity [72], industry characteristics and product life cycles [75], changes in customer preferences [76], and changes in government policies [77].

\subsection{Implications}

Our study provides several important theoretical and practical implications. From a theoretical perspective, first, in order to help clarify the relationships between environments and innovation, our study makes an initial attempt to examine a mediation effect of external knowledge acquisition on their relationships, based on organizational learning and knowledge-based perspectives. Previous studies have focused on the direct effects of environments in terms of dynamism, complexity, and hostility on innovation, mostly ignoring the indirect effects of environments on innovation through a mediator, despite that an intermediary mechanism may play a role in linking environments with innovation more tightly. As such, our study fills an important gap in the literature by proposing and empirically validating that external knowledge acquisition is a critical mediating mechanism between environments and innovation. Second, it is suggested that the direct relationships between environments and innovation discussed in prior studies may be spurious in nature, since our results clearly show that the relationships are completely mediated by external knowledge acquisition. In the case where the direct positive effects of environments on innovation disappear completely when external knowledge acquisition is taken into account as a mediator, it can be inferred that solid direct relationships between environments and innovation may not have existed inherently in the first place. In this sense, the inconsistent results of extant research on the relationships between environments and innovation, as discussed in the introduction section, may have been caused by this potentially spurious nature of the relationships. Third, in relation to the second theoretical implication, the study further suggests that, for a better understanding of the relationships between environments and innovation, other intermediary mechanisms (in addition to external knowledge acquisition) to connect environments with innovation more closely need to be investigated, since environments and innovation are believed to be fairly apart from each other.

Furthermore, from a practical perspective, our study indicates that it is essential to acquire knowledge from outside before firms can improve their innovation when they face dynamic, complex, or hostile environments. Unlike what extant research claims, dynamic, complex and hostile environments alone do not enhance firms' innovation directly or automatically, but rather such environments can increase firms' innovation outputs through the intermediary mechanism of firms' external knowledge acquisition. In other words, our study suggests to managers that, to achieve higher innovation outputs, firms are required to make efforts to secure new knowledge regarding their dynamic, complex, or hostile environments from various external sources. More specifically, managers should bear in mind that firms operating in dynamic environments can improve innovation in terms of product, process, market, and management by acquiring new external knowledge about changing 
environments in technologies and markets from such sources as suppliers, buyers, competitors, and alliance or network partners. Similarly, managers should remember that, when facing complex environments, firms can increase innovation outputs through the acquisition of new knowledge regarding diverse technologies, products, markets, and management processes and systems from various external sources. Besides, managers should also keep in mind that it is essential for firms under hostile environments to secure new knowledge with regard to unfavorable or adverse external conditions like severe competition, tight regulations, and limited resources to increase their innovative capability and innovation outputs.

\subsection{Limitations and Future Research}

These conclusions and implications need be considered alongside the following limitations of the study, which may suggest a need for potential future research. First, the context of this research focused on small and medium-sized manufacturing firms headquartered in Beijing, China. This narrowly defined target population may limit the generalization of our research results. Therefore, it seems desirable for future studies to evaluate the generalizability of our results by expanding their research context to a broader range of geographies, industries, and firms. Second, like most survey research, the study collected data for measuring both independent and dependent variables from a single respondent, which may imply the possibility of common method bias. Harman's one-factor test was employed to check for this potential bias, and the test revealed that there was little threat of notable common method bias. However, given that Harman's one-factor test itself has limitations [51], the potential of this bias in our study may not be completely ruled out. Therefore, future studies on this research issue should try to collect data from multiple respondents to resolve this limitation. Third, because we used innovation as a second-order construct in our study, we could not deal with the individual types of innovation—product, process, market, and management-and could not address how each of these innovation types matters for different environments and external knowledge acquisition. Firms' external knowledge acquisition under different environments may have varying effects on different innovation types. Hence, it seems desirable for future studies to deal with the individual types of innovation for more detailed analyses. Fourth, our study focused on only knowledge acquisition from outside as an intervening mechanism between environments and innovation, excluding other relevant learning processes of knowledge transformation and exploitation [78]. However, these other learning processes may also play important mediation roles and provide additional insights into this research issue. Thus, future studies should try to deal with the mediation effects of knowledge transformation and exploitation on the relationships between environments and innovation.

Author Contributions: Conceptualization: K.K. and F.L.; methodology: C.Y.K. and J.W.Y.; data collection: F.L.; Analysis: C.Y.K.; validation: J.W.Y.; writing: K.K. and C.Y.K; reviewing and editing: J.W.Y.; revision and resubmission process: C.Y.K. All authors have read and agreed to the published version of the manuscript.

Funding: This research was funded by Konkuk University, grant number 2016-A019-0532 and the APC was funded by the same project.

Conflicts of Interest: The authors declare no conflict of interest. 


\section{Appendix A}

Table A1. Prior Research on the Effects of Environments on Innovation or Innovativeness.

\begin{tabular}{|c|c|c|c|c|}
\hline Authors & Dependent Variable(s) & Independent Variable(s) & Result & Sample \\
\hline Bodlaj \& Čater [1] & Innovativeness & $\begin{array}{l}\text { Market turbulence }(+) \\
\text { Technological turbulence }(+) \\
\text { Competitive intensity }(+)\end{array}$ & $\begin{array}{l}+ \\
x \\
x\end{array}$ & 373 SMEs in Europe \\
\hline $\begin{array}{c}\text { Kach, Busse, Azadegan \& } \\
\text { Wagner [2] }\end{array}$ & $\begin{array}{l}\text { Product Innovativeness } \\
\text { Process Innovativeness }\end{array}$ & $\begin{array}{c}\text { Market decline }(-,-) \\
\text { Restrictiveness }(-,+) \\
\text { Competition }(+,+) \\
\text { Resource Scarcity }(-,+)\end{array}$ & $\begin{array}{l}-, x \\
-,+ \\
+,+ \\
-,+\end{array}$ & 148 SMEs in US \\
\hline Miller \& Friesen [3] & Innovation & $\begin{array}{c}\text { Dynamism }(+), \text { Hostility }(-) \\
\text { Complexity }(+)\end{array}$ & $\begin{array}{c}+,+ \\
+\end{array}$ & $\begin{array}{l}128 \text { firms in US and } \\
\text { Canada }\end{array}$ \\
\hline Tajeddini \& Trueman [4] & Innovativeness & $\begin{array}{c}\text { Complicated }(+), \text { Dynamic }(+) \\
\text { Hostile }(+)\end{array}$ & $\begin{array}{c}+,+ \\
x\end{array}$ & 127 SOEs in Iran \\
\hline Pervan, Al-Ansaari \& Xu [5] & Innovation & Market dynamism (+) & + & 200 SMEs in Dubai \\
\hline $\begin{array}{c}\text { Martinez-Conesa, Soto-Acosta \& } \\
\text { Carayannis [6] }\end{array}$ & Open Innovation & Environmental dynamism (+) & + & 429 SMEs in Spain \\
\hline Prajogo \& McDermott [7] & $\begin{array}{l}\text { Exploratory innovation } \\
\text { Exploitative innovation }\end{array}$ & $\begin{array}{l}\text { Environmental uncertainty } \\
\qquad(+,+) \\
\text { Environmental hostility }(-,+)\end{array}$ & $\begin{array}{l}+,+ \\
-,-\end{array}$ & 196 SMEs in Australia \\
\hline Prajogo \& McDermott [7] & $\begin{array}{l}\text { Exploratory innovation } \\
\text { Exploitative innovation }\end{array}$ & $\begin{array}{l}\text { Environmental uncertainty } \\
\qquad(+,+) \\
\text { Environmental hostility }(-,+)\end{array}$ & $\begin{array}{l}+,+ \\
-,-\end{array}$ & 196 SMEs in Australia \\
\hline Lee \& Tang [8] & Innovation orientation & $\begin{array}{c}\text { Dysfunctional competition }(+) \\
\text { Technological turbulence }(+)\end{array}$ & $\begin{array}{l}+ \\
+\end{array}$ & 147 firms in China \\
\hline $\begin{array}{c}\text { Calantone, Harmancioglu \& } \\
\text { Droge [9] }\end{array}$ & New Product Innovation & $\begin{array}{c}\text { Market Turbulence (+) } \\
\text { Technological Turbulence (+) }\end{array}$ & $\begin{array}{l}+ \\
x\end{array}$ & Meta-analysis \\
\hline
\end{tabular}


Table A1. Cont.

\begin{tabular}{|c|c|c|c|c|}
\hline Authors & Dependent Variable(s) & Independent Variable(s) & Result & Sample \\
\hline $\begin{array}{c}\text { Uzkurt, Kumar, Kimzan \& Sert } \\
\text { [10] }\end{array}$ & Innovativeness & $\begin{array}{l}\text { Competitive intensity }(+) \\
\text { Market turbulence }(+) \\
\text { Technological turbulence }(+)\end{array}$ & $\begin{array}{l}\mathrm{x} \\
+ \\
+\end{array}$ & 156 SMEs in Turkey \\
\hline Alexandrova [11] & Innovativeness & $\begin{array}{c}\text { Environmental uncertainty (+) } \\
\text { Environmental hostility (+) } \\
\text { Environmental dynamism (+) }\end{array}$ & $\begin{array}{l}+ \\
- \\
+\end{array}$ & 382 micro-firms in Bulgaria \\
\hline $\begin{array}{c}\text { Tuominen, Rajala, Möller \& } \\
\text { Anttila [12] }\end{array}$ & $\begin{array}{c}\text { Innovativeness: } \\
\text {-new product development } \\
\text {-commercialization }\end{array}$ & $\begin{array}{c}\text { Environmental Dynamism: } \\
\text { Technology-based }(+,+) \\
\text { Market-based }(+,+)\end{array}$ & $\begin{array}{r}+, x \\
x, x\end{array}$ & 140 in Finnish \\
\hline Abdallah \& Persson [13] & Innovativeness & $\begin{array}{l}\text { Environmental uncertainty: } \\
\text { Technological turbulence }(+) \\
\text { Competitive intensity }(+)\end{array}$ & $\begin{array}{l}\mathrm{x} \\
+\end{array}$ & 250 SME's in Sweden. \\
\hline
\end{tabular}

Note: + , positive relationship; -, negative relationship; $x$, no relationship. 


\section{Appendix B : Measure for Innovation}

\section{Product Innovation:}

1. Our company often develops new products well accepted by the market

2. A great majority of our company's profits are generated by the new products developed

3. The new products developed by our company always arouse imitation from competitors

4. Our company often launches new products faster than our competitors

5. Our company has better capability in R\&D of new products than our competitors

\section{Process Innovation:}

1. Our company often tries different operation procedures to hasten the realization of the company's goals

2. Our company always acquires new skills or equipment to impr-ove the production operation

3. Our company develops more efficient production process or operation procedure

4. Our company flexibly provides products according to the demands of the customers

5. The new production process or operation procedure employed by our company always arouses imitation from competitors

Market Innovation:

1. Our company enters new market segments more often than similar companies

2. In comparison with its competitors, our company's most recent product marketing program is revolutionary in the market

3. Our company adopts new approaches to enter and exploit the target market

4. Our company renews distribution channels, pricing techniques, and promotion techniques

5. Our company enters market segments that are novel to the industry

\section{Management Innovation:}

1. Our company adopts the innovative financial management systems that effectively monitors the actual discrepancy between our performance and our goals

2. Our company emphasizes innovative and creative capability when recruiting staff/employees

3. Our company renews the routines, procedures, and processes employed to execute firm activities innovatively

4. Our company renews the supply chain management system

5. Our company adopts innovative management systems and practices

6. Our company renews the organization structure to facilitate teamwork

\section{References}

1. Bodlaj, M.; Cater, B. The Impact of Environmental Turbulence on the Perceived Importance of Innovation and Innovativeness in SMEs. J. Small Bus. Manag. 2019, 57, 417-435. [CrossRef]

2. Kach, A.; Busse, C.; Azadegan, A.; Wagner, S.M. Maneuvering through Hostile Environments: How Firms Leverage Product and Process Innovativeness. Decis. Sci. 2016, 47, 907-956. [CrossRef]

3. Miller, D.; Friesen, P.H. Strategy-making and environment: The third link. Strat. Manag. J. 1983, 4, $221-223$. [CrossRef]

4. Tajeddini, K.; Trueman, M. Environment-Strategy and Alignment in a Restricted, Transitional Economy: Empirical Research on its Application to Iranian State-Owned Enterprises. Long Range Plan. 2016, 49, 570-583. [CrossRef]

5. Pervan, S.; Al-Ansaari, Y.; Xu, J. Environmental determinants of open innovation in Dubai SMEs. Ind. Mark. Manag. 2015, 50, 60-68. [CrossRef] 
6. Martinez-Conesa, I.; Soto-Acosta, P.; Carayannis, E.G. On the path towards open innovation: Assessing the role of knowledge management capability and environmental dynamism in SMEs. J. Knowl. Manag. 2017, 21, 553-570. [CrossRef]

7. Prajogo, D.; McDermott, C.M. Antecedents of Service Innovation in SMEs: Comparing the Effects of External and Internal Factors. J. Small Bus. Manag. 2013, 52, 521-540. [CrossRef]

8. Lee, R.P.; Tang, X. Does It Pay to Be Innovation and Imitation Oriented? An Examination of the Antecedents and Consequences of Innovation and Imitation Orientations. J. Prod. Innov. Manag. 2017, 35, 11-26. [CrossRef]

9. Calantone, R.J.; Harmancioglu, N.; Droge, C. Inconclusive Innovation "Returns": A Meta-Analysis of Research on Innovation in New Product Development. J. Prod. Innov. Manag. 2010, 27, 1065-1081. [CrossRef]

10. Uzkurt, C.; Kumar, R.; Kimzan, H.S.; Sert, H. The impact of environmental uncertainty dimensions on organisational innovativeness: An empirical study on smes. Int. J. Innov. Manag. 2012, 16, 1250015. [CrossRef]

11. Alexandrova, M. Entrepreneurship in transition economy: The impact of environment on entrepreneurial orientation. Probl. Perspect. Manag. 2004, 2, 140-148.

12. Tuominen, M.; Rajala, A.; Möller, K.; Anttila, M. Assessing innovativeness through organisational adaptability: A contingency approach. Int. J. Technol. Manag. 2003, 25, 643-658. [CrossRef]

13. Abdallah, L.; Persson, M. The Effects of Environmental Uncertainty Conditions on Organisational Innovativeness and Performance of SMEs. Master's Thesis, Blekinge Institute of Technology School of Management, Karlskrona, Sweden, 2014.

14. Venkatraman, N. The concept of fit in strategy research: Toward verbal and statistical correspondence. Acad. Manage. Rev. 1989, 14, 423-444. [CrossRef]

15. Hayes, A.F. Introduction to Mediation, Moderation, and Conditional Process Analysis: A Regression-Based Approach, 2nd ed.; Guilford Press: New York, NY, USA, 2017.

16. AL-Nuiami, M.; Idris, W.M.S.; AL-Ferokh, F.A.M.; Joma, M.H.M.A. An Empirical Study of the Moderator Effect of Entrepreneurial Orientation on the Relationship between Environmental Turbulence and Innovation Performance in Five-star Hotels in Jordan. Int. J. Bus. Adm. 2014, 5, 111-125. [CrossRef]

17. Rodrigo-Alarcón, J.; Garcia-Villaverde, P.M.; Parra-Requena, G.; Ruiz-Ortega, M.J. Innovativeness in the context of technological and market dynamism. J. Organ. Chang. Manag. 2017, 30, 548-568. [CrossRef]

18. Özsomer, A.; Calantone, R.J.; Di Bonetto, A. What makes firms more innovative? A look at organizational and environmental factors. J. Bus. Ind. Mark. 1997, 12, 400-416. [CrossRef]

19. Flatten, T.C.; Engelen, A.; Zahra, S.A.; Brettel, M. A measure of absorptive capacity: Scale development and validation. Eur. Manag. J. 2011, 29, 98-116. [CrossRef]

20. Petti, C.; Tang, Y.; Margherita, A. Technological innovation vs technological backwardness patterns in latecomer firms: An absorptive capacity perspective. J. Eng. Technol. Manag. 2019, 51, 10-20. [CrossRef]

21. Zahra, S.A.; George, G. Absorptive capacity. A review, reconceptualization and extension. Acad. Manag. Rev. 2002, 27, 185-203. [CrossRef]

22. Huber, G. Organizational learning: The contributing processes and a review of the literatures. Organ. Sci. 1991, 2, 88-115. [CrossRef]

23. Grant, R.M. Toward a knowledge-based theory of the firm. Strat. Manag. J. 1996, 17, 109-122. [CrossRef]

24. Porter, M.E. Competitive Strategy: Techniques for Analyzing Industries and Competitors; Free Press: New York, NY, USA, 1980.

25. Dess, G.G.; Beard, D.W. Dimensions of Organizational Task Environments. Adm. Sci. Q. 1984, $29,52-73$. [CrossRef]

26. Child, J. Organizational Structure, Environment and Performance: The Role of Strategic Choice. Sociology 1972, 6, 1-22. [CrossRef]

27. Damanpour, F.; Schneider, M. Phases of the Adoption of Innovation in Organizations: Effects of Environment, Organization and Top Managers1. Br. J. Manag. 2006, 17, 215-236. [CrossRef]

28. Damanpour, F. Organizational innovation: A meta-analysis of effects of determinants and moderators. Acad. Manag. J. 1991, 34, 555-590.

29. Hurley, R.F.; Hult, G.T.M. Innovation, market orientation, and organizational learning: An integration and empirical examination. J. Mark. 1998, 62, 42-54. [CrossRef] 
30. Schumpeter, J.A. The Theory of Economic Development: An Inquiry Into Profits, Capital, Credit, Interest, and the Business Cycle; Harvard University Press: Cambridge, MA, USA, 1934.

31. Oslo Manual. Guidelines for Collecting and Interpreting Innovation Data, 3rd ed.; OECD, European Commission: Brussel, Belgium, 2005.

32. Liao, S.-H.; Fei, W.-C.; Chen, C.-C. Knowledge sharing, absorptive capacity, and innovation capability: An empirical study of Taiwan's knowledge-intensive industries. J. Inf. Sci. 2007, 33, 340-359. [CrossRef]

33. Wang, C.L.; Ahmed, P.K. The development and validation of the organisational innovativeness construct using confirmatory factor analysis. Eur. J. Innov. Manag. 2004, 7, 303-313. [CrossRef]

34. Lee, H.; Kim, N.; Kwak, K.; Kim, W.; Soh, H.; Park, K. Diffusion Patterns in Convergence among High-Technology Industries: A Co-Occurrence-Based Analysis of Newspaper Article Data. Sustainability 2016, 8, 1029. [CrossRef]

35. Chesbrough, H.W. Open Innovation. The New Imperative for Creating and Profiting from Technology; Harvard Business School Press: Boston, MA, USA, 2003.

36. Sullivan, D.M.; Marvel, M.R. Knowledge Acquisition, Network Reliance, and Early-Stage Technology Venture Outcomes. J. Manag. Stud. 2011, 48, 1169-1193. [CrossRef]

37. Kim, C.Y.; Lim, M.S.; Yoo, J.W. Ambidexterity in External Knowledge Search Strategies and Innovation Performance: Mediating Role of Balanced Innovation and Moderating Role of Absorptive Capacity. Sustainability 2019, 11, 5111. [CrossRef]

38. Kim, D.-H.; Sambou, M.O.; Jung, M.-S. Does Technology Transfer Help Small and Medium Companies? Empirical Evidence from Korea. Sustainability 2016, 8, 1119. [CrossRef]

39. Khandwalla, P.N. Generators of Pioneering-Innovative Management: Some Indian Evidence. Organ. Stud. 1987, 8, 39-59. [CrossRef]

40. Bettis, R.A.; Hitt, M.A. The new competitive landscape. Strat. Manag. J. 1995, 16, 7-19. [CrossRef]

41. Lumpkin, G.T.; Dess, G.G. Linking two dimensions of entrepreneurial orientation to firm performance: The moderating role of environment and industry life cycle. J. Bus. Ventur. 2001, 16, 429-451. [CrossRef]

42. Elia, G.; Margherita, A. Assessing the maturity of crowd venturing for corporate entrepreneurship. Bus. Horiz. 2018, 61, 271-283. [CrossRef]

43. Tidd, J. Innovation management in context: Environment, organization and performance. Int. J. Manag. Rev. 2001, 3, 169-183. [CrossRef]

44. KPMG International. Confronting Complexity, KPMG International Cooperative. 2011. Available online: https://assets.kpmg/content/dam/kpmg/ru/pdf/2016/8/ru-ru-confronting-complexity.pdf (accessed on 2 July 2020).

45. Covin, J.G.; Slevin, D.P. Strategic management of small firms in hostile and benign environments. Strat. Manag. J. 1989, 10, 75-87. [CrossRef]

46. Potter, D.V. Rare mettle: Gold and silver strategies to succeed in hostile markets. Calif. Manag. Rev. 1994, 37, 65-82. [CrossRef]

47. The Korea Herald Home Page. Available online: http://www.koreaherald.com/view.php?ud=20200504000521 (accessed on 2 July 2020).

48. Milliken, F.J. Three types of perceived uncertainty about the environment: State, effect, and response uncertainty. Acad. Manag. Rev. 1997, 12, 133-143. [CrossRef]

49. Duncan, R.B. Characteristics of Organizational Environments and Perceived Environmental Uncertainty. Adm. Sci. Q. 1972, 17, 313-327. [CrossRef]

50. Xie, X.; Wang, L.; Zeng, S. Inter-organizational knowledge acquisition and firms' radical innovation: A moderated mediation analysis. J. Bus. Res. 2018, 90, 295-306. [CrossRef]

51. Podsakoff, P.M.; MacKenzie, S.B.; Lee, J.-Y.; Podsakoff, N.P. Common method biases in behavioral research: A critical review of the literature and recommended remedies. J. Appl. Psychol. 2003, 88, 879-903. [CrossRef] [PubMed]

52. Podsakoff, P.M.; Organ, D.W. Self-Reports in Organizational Research: Problems and Prospects. J. Manag. 1986, 12, 531-544. [CrossRef]

53. Fuentes-Fuentes, M.D.M.; Albacete-Sáez, C.A.; Llorens-Montes, F.J. The impact of environmental characteristics on TQM principles and organizational performance. Omega 2004, 32, 425-442. [CrossRef]

54. Li, D.-Y.; Liu, J. Dynamic capabilities, environmental dynamism, and competitive advantage: Evidence from China. J. Bus. Res. 2014, 67, 2793-2799. [CrossRef] 
55. Sutcliffe, K.M.; Huber, G.P. Firm and industry as determinants of executive perceptions of the environment. Strat. Manag. J. 1998, 19, 793-807. [CrossRef]

56. Newkirk, H.E.; Lederer, A.L. The effectiveness of strategic information systems planning under environmentaluncertainty. Inf. Manag. 2006, 43, 481-501. [CrossRef]

57. Khandwalla, P.N. Some top management styles, their context and performance. Adm. Sci. Q. 1977, 7, $21-51$.

58. Slevin, D.P.; Covin, J.G. Strategy Formation Patterns, Performance, and the Significance of Context. J. Manag. 1997, 23, 189-209. [CrossRef]

59. Bojica, A.M.; Fuentes-Fuentes, M.D.M. Knowledge acquisition and corporate entrepreneurship: Insights from Spanish SMEs in the ICT sector. J. World Bus. 2012, 47, 397-408. [CrossRef]

60. Li, Y.; Liu, Y.; Liu, H. Co-opetition, distributor's entrepreneurial orientation and manufacturer's knowledge acquisition: Evidence from China. J. Oper. Manag. 2011, 29, 128-142. [CrossRef]

61. Tsai, W. Knowledge transfer in intraorganizational networks: Effects of network position and absorptive capacity on business unit innovation and performance. Acad. Manag. J. 2001, 44, 996-1004.

62. Turulja, L.; Bajgorić, N. Innovation, firms' performance and environmental turbulence: Is there a moderator or mediator? Eur. J. Innov. Manag. 2019, 22, 213-232. [CrossRef]

63. Holmbeck, G. Toward terminological, conceptual, and statistical clarity in the study of mediators and moderators: Examples from the child-clinical and pediatric psychology literatures. J. Consult. Clin. Psychol. 1997, 65, 599-610. [CrossRef]

64. Hair, J.; Anderson, R.; Tatham, R.; Black, W. Multivariate Data Analysis, 5th ed.; Prentice Hall: Upper Saddle River, NJ, USA, 1998.

65. Anderson, J.C.; Gerbing, D.W. Structural equation modeling in practice: A review and recommended two step approach. Psychol. Bull. 1988, 103, 411-423. [CrossRef]

66. Nunnally, J.C. Psychometric Theory; McGraw-Hill: New York, NY, USA, 1967.

67. Fornell, C.; Larcker, D.F. Evaluating structural equation models with unobservable variables and measurement error. J. Mark. Res. 1981, 18, 39-50. [CrossRef]

68. Bentler, P.M.; Chou, C.-P. Practical Issues in Structural Modeling. Sociol. Methods Res. 1987, 16, 78-117. [CrossRef]

69. Baron, R.M.; Kenny, D.A. The moderator-mediator variable distinction in social psychological research: Conceptual, strategic, and statistical considerations. J. Pers. Soc. Psychol. 1986, 51, 1173-1182. [CrossRef]

70. Hu, L.; Bentler, P.M. Cutoff criteria for fit indexes in covariance structure analysis: Conventional criteria versus new alternatives. Struct. Equ. Model. 1999, 6, 1-55. [CrossRef]

71. Falk, R.F.; Miller, N.B. A Primer for Soft Modeling; University of Akron Press: Akron, OH, USA, 1992.

72. Yun, J.J.; Won, D.; Park, K. Dynamics from open innovation to evolutionary change. J. Open Innov. Technol. Mark. Complex. 2016, 2, 7-22. [CrossRef]

73. Kim, Y.; Lee, M. Typology and Unified Model of the Sharing Economy in Open Innovation Dynamics. J. Open Innov. Technol. Mark. Complex. 2019, 5, 102. [CrossRef]

74. Rasiah, R. Building Networks to Harness Innovation Synergies: Towards an Open Systems Approach to Sustainable Development. J. Open Innov. Technol. Mark. Complex. 2019, 5, 70. [CrossRef]

75. Spithoven, A.; Clarysse, B.; Knockaert, M. Building absorptive capacity to organise inbound open innovation in traditional industries. Technovation 2011, 31, 10-21. [CrossRef]

76. Oganisjana, K.; Kozlovskis, K. The Identification of Opportunities for Innovations through Collecting Problems from Citizens. J. Open Innov. Technol. Mark. Complex. 2019, 5, 76. [CrossRef]

77. Yun, J.J. How do we conquer the growth limits of capitalism? Schumpeterian Dynamics of Open Innovation. J. Open Innov. Technol. Mark. Complex. 2015, 1, 17-20. [CrossRef]

78. Lane, P.J.; Koka, B.R.; Pathak, S. The Reification of Absorptive Capacity: A Critical Review and Rejuvenation of the Construct. Acad. Manag. Rev. 2006, 31, 833-863. [CrossRef]

(C) 2020 by the authors. Licensee MDPI, Basel, Switzerland. This article is an open access article distributed under the terms and conditions of the Creative Commons Attribution (CC BY) license (http://creativecommons.org/licenses/by/4.0/). 